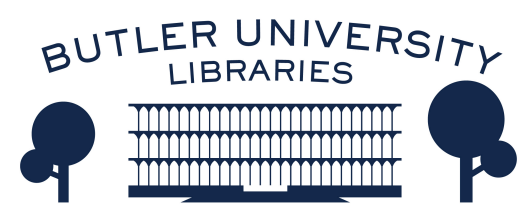

Journal of Hindu-Christian Studies

January 2004

\title{
Book Review: "Imagining Hinduism: A Postcolonial Perspective"
}

\author{
Deepak Sarma
}

Follow this and additional works at: https://digitalcommons.butler.edu/jhcs

Part of the Religion Commons

\section{Recommended Citation}

Sarma, Deepak (2004) "Book Review: "Imagining Hinduism: A Postcolonial Perspective"," Journal of Hindu-Christian Studies: Vol. 17, Article 22.

Available at: https://doi.org/10.7825/2164-6279.1331

The Journal of Hindu-Christian Studies is a publication of the Society for Hindu-Christian Studies. The digital version is made available by Digital Commons @ Butler University. For questions about the Journal or the Society, please contact cbauman@butler.edu. For more information about Digital Commons @ Butler University, please contact digitalscholarship@butler.edu. 
bishops. The book is a valuable window into religious life in Asia.

Edward T. Ulrich

University of St. Thomas

\section{Imagining Hinduism: A Postcolonial Perspective. Sharada Sugirtharajah. New York: Routledge, 2003, xviii + 164 pp.}

THE current trend in South Asian studies is to uncover the colonial and hegemonic biases of the earliest (and usually British) Indologists. The end result has been the "post-colonial industry" and an overwhelming number of articles and monographs, some of which are only mediocre. A variety of cutting edge and carefully crafted treatises are thus joined by other less successful efforts. Sugirtharajah's Imagining Hinduism: $A$ Postcolonial Perspective, despite its catchy title, is one such book that is less valuable than other studies.

Though Sugirtharajah promises a new perspective, hers merely repeats arguments made by scores of scholars in the past namely, that Hinduism has been imagined through the eyes of colonizers whose agenda was colonizing and oppressive. The imagination of these tyrannical Indologists, moreover, affected the ways that Hindus have imagined themselves, just as an abused child might incorrectly believe that $\mathrm{s} / \mathrm{he}$ is obese after being repeatedly told so by her/his parents. To this end, Sugirtharajah "exposes" William Jones in chapter one, Max Müller in chapter two, William Ward and John Nichol Farquhar in chapters three and four, and finally, Julia Leslie in chapter five. The chapters do not flow well with one another and Sugirtharajah explains that her volume is "not designed with a linear progression in mind" (xvii). Despite her warning (or justification), the volume remains disjointed and fragmented.

The historical and other data that she organizes is commendable and some may find it to be interesting. Jones, for example, believed that the Vedas were composed before the Christian Flood and that the Indian god Rama was associated with the Biblical Ramah (9-10). Furthermore, according to Sugirtharajah, Müller's intentions behind the translations of the Sacred Books of the East were not purely academic. Instead, Müller thought that they "will do a great deal towards lifting Christianity into its high historical position"(63). Though some readers may be horrified, Müller's proposal merely reminded me of other theologian-scholarcomparativists such as Rudolf. Otto who proposed similar agenda and structures.

Her presentation of these historical facts soon becomes repetitive and rather tedious. Stylistic errors abound. She uses identical introductory phrases several times in a single paragraph. For example, when introducing a quote, she far too frequently does so by prefixing it with "As [so-and-so] says." This is a bit wearying for the reader.

Though these stylistic blunders can be overlooked, the first four chapters suffer from a far larger problem that concerns her application of a post-colonial perspective to missionary activities. She thus frames Jones, Müller and Ward as Christian missionaries who hid behind an academic veil, whose presentations of Hinduism to their Christian readers and audience should be questioned, and whose methodologies reveal missionary agendas. Sugirtharajah seems unaware of the typical strategies of missionaries and proselytizers who believe that their religion has an exclusive claim to truth and is 
superlative. Why should it be any surprise or insightful criticism that Jones and others write as missionaries and that their evaluations or judgments of Hindu texts and practices are not flattering? In fact, it would be a surprise if they were! The issue is now an old one and concerns the legitimacy and practice of conversion addressed by Gauri Viswanathan in her groundbreaking work, Outside the Fold: Conversion, Modernity, and Belief (Princeton University Press, 1998) (which, Sugirtharajah does not mention at all in her book despite the centrality of the themes), among others. Is it unfair or wrong to misrepresent one's opponents' positions, as Sugirtharajah would have the reader believe? The implication of this perspective would restrict many a politician! For that matter, when scores of Indian philosophers present their opponent's position as "straw-men" in a samvada (debate), then they are no better than the missionary Christians. Shame on Madhava for doing the same in his Sarvadarsana Samgraha! How about a postcolonial perspective on samvada? Sugirtharajah's application of post-colonial interpretive strategies is thus anachronistic: Jones et al did not live in a utopian, politically correct, pluralistic, and multicultural world. Her application of a postcolonial methodology, then, is not fruitful, for it fails to provide much new or surprising information.

Sugirtharajah also fails in her pledge to correlate her research with issues in contemporary India and in the Diaspora. She touches upon a wide variety of issues and controversies including the right-wing Hindu fundamentalists in India (BJP, VHP, RSS), ISKCON, Swami Narayanan, and the Christian background and agendas of the early Indologists. Though she mentions all of the important players and concepts, the reader is still left with a feeling that Sugirtharajah is gesturing at the tips of very large icebergs.

So, I do not recommend this book. It promises far more than it delivers and is founded on poorly hidden meta-claims about the appropriateness (or in this case, inappropriateness) of missionary activities and inter-religious dialogue. My criticism of Sugirtharajah's book is perhaps a larger indictment of a methodology that seems to have dominated the academic world yet increasingly sounds like a broken record.

Deepak Sarma

Case Western Reserve University

\section{Briefly Noted}

Encountering Kali: In the Margins, at the Center, in the West. Edited by Rachel Fell McDermott and Jeffrey J. Kripal. Berkeley: University of California Press, 2003, xviii + $321 \mathrm{pp}$.

This beautifully produced state-of-the-art review of Kali Studies is also a tribute to David Kinsley (died, April 2000) whose book, The Sword and the Flute (1975) initiated contemporary phenomenological and historical studies of the goddess. Springing from a conference at Barnard College in 1996, this team-authored, interdisciplinary volume is enriched with artwork from Venantius Pinto and wonderful visual reproductions. The book aims to analyze the promises and problems involved in meeting and interpreting the Hindu goddess Kali in her indigenous South Asian settings and in her more recent Western reincarnations. Thus the approach is cross-cultural. Although probably originally a tribal goddess, by the epic and early puranic periods (third century B.C.E. to seventh century C.E.), Kali is described as being absorbed into the Brahmanical Sanskrit tradition as a dangerous, bloodloving battle queen, the incarnation of the goddess Durga's fury. During the eighth to the sixteenth centuries C.E., the Tantric tradition elevated Kali to an ontological 